\title{
Impact of Basal Forebrain Cholinergic Inputs on Basolateral Amygdala Neurons
}

\author{
Cagri T. Unal, Denis Pare, and Laszlo Zaborszky \\ Center for Molecular and Behavioral Neuroscience, Rutgers, The State University, Newark, New Jersey 07102
}

In addition to innervating the cerebral cortex, basal forebrain cholinergic $(\mathrm{BFc})$ neurons send a dense projection to the basolateral nucleus of the amygdala (BLA). In this study, we investigated the effect of near physiological acetylcholine release on BLA neurons using optogenetic tools and in vitro patch-clamp recordings. Adult transgenic mice expressing cre-recombinase under the choline acetyltransferase promoter were used to selectively transduce BFc neurons with channelrhodopsin-2 and a reporter through the injection of an adeno-associated virus. Light-induced stimulation of $\mathrm{BF}$ axons produced different effects depending on the BLA cell type. In late-firing interneurons, BFc inputs elicited fast nicotinic EPSPs. In contrast, no response could be detected in fast-spiking interneurons. In principal BLA neurons, two different effects were elicited depending on their activity level. When principal BLA neurons were quiescent or made to fire at low rates by depolarizing current injection, light-induced activation of BFc axons elicited muscarinic IPSPs. In contrast, with stronger depolarizing currents, eliciting firing above $\sim 6-8 \mathrm{~Hz}$, these muscarinic IPSPs lost their efficacy because stimulation of BFc inputs prolonged current-evoked afterdepolarizations. All the effects observed in principal neurons were dependent on muscarinic receptors type 1 , engaging different intracellular mechanisms in a state-dependent manner. Overall, our results suggest that acetylcholine enhances the signal-to-noise ratio in principal BLA neurons. Moreover, the cholinergic engagement of afterdepolarizations may contribute to the formation of stimulus associations during fear-conditioning tasks where the timing of conditioned and unconditioned stimuli is not optimal for the induction of synaptic plasticity.

Key words: acetylcholine; amygdala; emotion; fear; memory; state dependence

\section{Introduction}

Basal forebrain cholinergic $(\mathrm{BFc})$ neurons contribute dense projections to the entire cortical mantle (Zaborszky et al., 2011), particularly limbic areas (Mesulam, 2004), and to a few subcortical structures, such as the BLA (Ben-Ari et al., 1977; Nitecka and Frotscher, 1989). In both the neocortex and BLA, a subpopulation of interneurons expresses muscarinic type-2 (M2) receptors (Levey et al., 1991; McDonald and Mascagni, 2011) whereas principal cells express M1 receptors (Mrzljak et al., 1993; McDonald and Mascagni, 2010; Yamasaki et al., 2010). Pharmacological activation of muscarinic receptors elicits similar responses in principal neurons of the neocortex and BLA. Generally, it was found that ACh reduces spike afterhyperpolarizations and generates a slow EPSP through the inhibition of the M current (Metherate et al., 1992; Washburn and Moises, 1992; Womble and Moises, 1992, 1993; Pape and Driesang, 1998; Faber and Sah, 2002; Krnjević, 2004). However, in some cases, it was reported that the slow EPSP was found to be at least partly dependent on the activation of $I_{\mathrm{CAN}}$ (Yajeya et al., 1997, 1999).

Received July 3, 2014; revised Oct. 20, 2014; accepted Nov. 24, 2014.

Author contributions:C.T.U., D.P., and L.Z. designed research;C.T.U. performed research; C.T.U. and D.P. analyzed data; C.T.U., D.P., and L.Z. wrote the paper.

This work was supported by National Institutes of Health Grants 23945 to L.Z. and MH-098738 to D.P.

The authors declare no competing financial interests.

Correspondence should be addressed to Laszlo Zaborszky, Center for Molecular and Behavioral Neuroscience, Rutgers, The State University, 197 University Avenue, Newark, NJ 07102. E-mail: laszloz@andromeda.rutgers.edu. DOI:10.1523/JNEUROSCI.2706-14.2015

Copyright $\odot 2015$ the authors $\quad 0270-6474 / 15 / 350853-11 \$ 15.00 / 0$
Consistent with the high density of cholinergic inputs to BLA neurons, ACh strongly modulates performance on BLA-dependent tasks that probe the formation of emotional memories (Gold, 2003; Tinsley et al., 2004). For instance, local intra-BLA infusion of muscarinic antagonists during training interferes with subsequent memory performance in conditioned place-preference tasks (McIntyre et al., 1998). Consistent with this, the concentration of ACh increases markedly in the BLA during training on BLA-dependent tasks (McIntyre et al., 2003). Moreover, a strong correlation was found between individual variations in ACh release in the BLA during training and subsequent memory recall (McIntyre et al., 2003).

Until recently, the impact of cholinergic inputs on neocortical and BLA neurons was mainly studied using application of drugs in vitro. However, exogenous agonists possibly affect synaptic versus extrasynaptic receptors to different degrees than the physiological release of neurotransmitters, potentially eliciting effects that are not normally evoked by endogenous transmitter release. Thus, we aimed to study the impact of cholinergic inputs on BLA neurons under conditions that more closely reproduce normal ACh release and are therefore less likely to recruit extrasynaptic cholinergic receptors. To this end, we combined optogenetic tools (Zhang et al., 2007) and in vitro patch-clamp recordings from BLA neurons in acute slices. Adult transgenic mice expressing cre-recombinase under the promoter of ChAT were used to selectively transduce BFc neurons with channelrhodopsin-2 (ChR2) and a YFP through the injection of an AAV. Slices of the amygdala were prepared from AAV-injected mice and BFc inputs 
were selectively stimulated with blue light while recording BLA neurons.

Our results indicate that the impact of BFc inputs on principal BLA neurons depends on their level of activity: excitatory when they are strongly activated and inhibitory during quiescence. Overall, these results suggest that by reducing the excitability of less active neurons and enhancing that of the more active ones, $\mathrm{BFc}$ neurons increase signal-to-noise ratio in the BLA.

\section{Materials and Methods}

Procedures were approved by the Institutional Animal Care and Use Committee of Rutgers University, in compliance with the Guide for the Care and Use of Laboratory Animals (Department of Health and Human Services).

Animals and procedures for AAV infusions. All experiments were per-

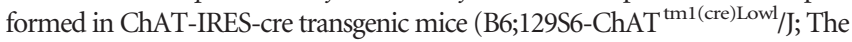
Jackson Laboratory) of either sex. When they were 2.5-3 months old, mice were anesthetized with isoflurane and placed in a stereotaxic apparatus $(n=31)$. They then received multiple subcutaneous injections of the local anesthetic bupivacaine in the region of the scalp to be incised. Ten minutes later, the skull was exposed and small holes were drilled above the regions of interest. We then performed bilateral infusions $(0.33 \mu \mathrm{l} /$ side) of an AAV (AAV2/5.EF1a.DIO.hChR2(H134R)-EYFP.WPRE.hGH; Penn Vector Core) in the basal forebrain [coordinates with respect to bregma (in $\mu \mathrm{m}$ ): AP: -700 , LM: 1750, DV: $4260 ; \sim 0.33 \mu \mathrm{l} \mathrm{each].} \mathrm{To} \mathrm{this}$ end, a glass pipette ( $\sim 50 \mu \mathrm{m}$ outer tip diameter) containing the concentrated virus stock solution was lowered to the appropriate depth using a Nanoject-2 (Drummond Scientific) pressure-injection apparatus. After the surgery, the animals were placed in a ventilated biosafety cabinet located in a quarantine room for $\geq 7 \mathrm{~d}$. The mice were used for electrophysiological recordings within 1.5-2 months of the AAV infusion (4-5 months old). In addition, three mice ranging in age between 4 and 12 months were used for anatomical experiments (see below).

Preparation of amygdala slices and electrophysiology. Mice were deeply anesthetized with ketamine and xylazine (150 and $30 \mathrm{mg} / \mathrm{kg}$, i.p., respectively) and transcardially perfused with $10 \mathrm{ml}$ of an ice-cold solution containing the following (in mM): $2.5 \mathrm{KCl}, 2.3 \mathrm{MgCl}_{2}, 26 \mathrm{NaHCO}_{3}, 1.2$ $\mathrm{NaHPO}_{4}, 10$ glucose, and 242 choline. The brains were then removed from the skull and 300- $\mu$ m-thick sections containing the BLA were obtained with a vibrating microtome using the same solution. BLA slices were then transferred to a holding chamber filled with an oxygenated (with 95\% $\mathrm{O}_{2}, 5 \% \mathrm{CO}_{2}$ ) ACSF solution containing the following (in mm): $124 \mathrm{NaCl}, 2.5 \mathrm{KCl}, 1.2 \mathrm{NaHPO}_{4}, 26 \mathrm{NaHCO}_{3}, 1.3 \mathrm{MgCl}_{2}, 2 \mathrm{CaCl}_{2}$, and 10 glucose. The osmolarity of the ACSF was $300 \pm 3 \mathrm{mOsm}$.

One hour or more later, one slice was transferred to a custom-made recording chamber superfused with oxygenated ACSF (3-5 ml/min) and kept at $32^{\circ} \mathrm{C}$. BLA neurons were visualized with an Olympus BX51WI microscope, equipped with infrared differential contrast optics and epifluorescence. Under visual guidance, we obtained whole-cell recordings of BLA neurons using pipettes $(3-6 \mathrm{M} \Omega)$ pulled from borosilicate glass capillaries and filled with a solution containing the following (in mM): $130 \mathrm{KMeSO}_{4}, 10$ $\mathrm{NaCl}, 2 \mathrm{MgCl}_{2}, 10$ HEPES, $3 \mathrm{Na}_{2} \mathrm{ATP}, 0.3 \mathrm{GTP}$, and 1 EGTA. With the exception of paired recordings, we patched a single cell per slice to minimize the risk that fiber fatigue developed as a result of light stimuli.

For perforated patch-clamp recordings, amphotericin $\mathrm{B}$ was dissolved in DMSO in a $60 \mathrm{mg} / \mathrm{ml}$ stock solution. A final concentration of 0.24 $\mathrm{mg} / \mathrm{ml}$ amphotericin was added into the intracellular solution. Stocks were prepared daily and final solutions were renewed approximately every $3 \mathrm{~h}$. To achieve successful recordings, the tips of pipettes were filled with amphotericin B-free solution. Generally, it took 30-45 min for the recordings to stabilize at an access resistance between 25 and $35 \mathrm{M} \Omega$. Access resistance was monitored at regular intervals ( $\sim 2 \mathrm{~min}$ ) during the recordings and calculated from the linear portion of the voltage response to a $-100 \mathrm{pA}$ intracellular current injection. In addition, we obtained measurements of access resistance before and after each experimental manipulation with the membrane test function of the pClamp software.
The access resistance of our perforated patch recordings (25-35 M $\Omega$ ) was not much higher than that typically accepted for whole-cell recordings $(<20 \mathrm{M} \Omega)$ in the literature. Moreover, the measurements we obtained [membrane potentials, afterdepolarizations (ADPs), and muscarinic IPSPs] are not very vulnerable to small perturbations in access resistance because they are slow events. Finally, we discarded all recordings that displayed abnormalities during current injections.

In all cases, Alexa $594(50 \mu \mathrm{M})$ was added into the intracellular solution. During perforated patch recordings, this allowed us to both ascertain the integrity of the perforated patch and visualize the dendrites of recorded neurons. To this end, at the end of the recordings, gentle suction was applied to rupture the patch and allow Alexa 594 to diffuse into the cells. In contrast, in whole-cell mode, Alexa 594 diffused throughout the cells during the recordings.

Current- and voltage-clamp recordings were obtained with an Axoclamp 900A amplifier and digitized at $10 \mathrm{kHz}$ with a Digidata $1440 \mathrm{~A}$ interface (Molecular Devices). Principal and local-circuit neurons of the BLA were distinguished using a combination of well established morphological and electrophysiological criteria (McDonald, 1992; Sah et al., 2003; Spampanato et al., 2011). Principal cells had densely spiny dendrites and generated spikes trains that exhibited variable degrees of spike frequency accommodation. Given that BLA interneurons exhibit heterogeneous firing patterns (Woodruff and Sah, 2007; Jasnow et al., 2009; Sosulina et al., 2010; Spampanato et al., 2011; Mańko et al., 2012), we relied primarily on morphological criteria (paucity of dendritic spines) to identify these cells.

Optogenetic activation of BFc axons was achieved with whole-field application of blue-light stimuli (460 nm, $5 \mathrm{~ms}$ pulses, every 15-30 s). $\mathrm{BFC}$ stimuli were paired with intracellular current pulses of varying amplitudes, the order of which was randomized. For each current intensity, we interspersed trials with and without stimulation of BFc axons.

In some experiments, we tested the effects of carbachol (CCh) in principal BLA neurons. CCh $(3 \mu \mathrm{M}$ or $10 \mu \mathrm{M})$ was applied via pressure ejection from a patch pipette or by addition of the drug to the perfusate. For pressure applications, patch pipettes containing CCh (dissolved in ACSF) were positioned at proximity $(\sim 50 \mu \mathrm{M})$ of the recorded neurons. Pressure $(\sim 10 \mathrm{psi})$ was applied to the back of the pipette with a $10 \mathrm{cc}$ syringe. In the CCh experiments, only one cell per slice was tested to avoid receptor desensitization.

Analyses and statistics. Electrophysiological data were analyzed off-line using Clampfit 10 (Molecular Devices). The onset of muscarinic IPSPs was defined as the time after the end-of-light stimuli when the membrane potential became more negative than prestimulus values. Their amplitude was measured by averaging membrane potential values during a 10 ms segment centered on their peak. Their offset was defined as the time when membrane potential values returned to baseline. The onset of ADPs was defined as the time when, following offset of depolarizing current pulses, the membrane potential became more positive than baseline (prestimulus) values. Peak ADP amplitudes were measured by averaging the membrane potential values during a $100 \mathrm{~ms}$ segment centered on their peak. ADP offset was defined as the point where the membrane potential returned to prepulse values. For assessing the relation between current-evoked firing frequency and the amplitude of the ensuing ADPs, we used a polynomial fit with a minimum number of terms that result in residuals accounting for a $p$ of 0.05 or less. During pharmacology experiments with carbachol, input resistance was regularly monitored with $-100 \mathrm{pA}$ current pulses. Means were compared with two-tailed Student's $t$ tests using SPSS software. The threshold $p$ value for significance was 0.05 .

Biocytin visualization. Following recordings with biocytin in the pipette $(0.2 \%)$, slices were transferred to $4 \%$ paraformaldehyde for at least $24 \mathrm{~h}$ for fixation. For biocytin visualization, slices were incubated in 1:200 Cy3-conjugated streptavidin or Texas Red-conjugated streptavidin (Invitrogen; Jackson ImmunoResearch) for 20-24 h. Slices were then transferred to a slide and mounted with Vectashield wet mounting medium (Vector Laboratories). For the acquisition of digital images Adobe Photoshop was used with an AxioCam camera attached to a Zeiss microscope. In some cases, neuronal morphology was revealed using nickel-3,4 diaminobenzidine $(\mathrm{Ni}-\mathrm{DAB})$ as follows: the slices were washed first in 

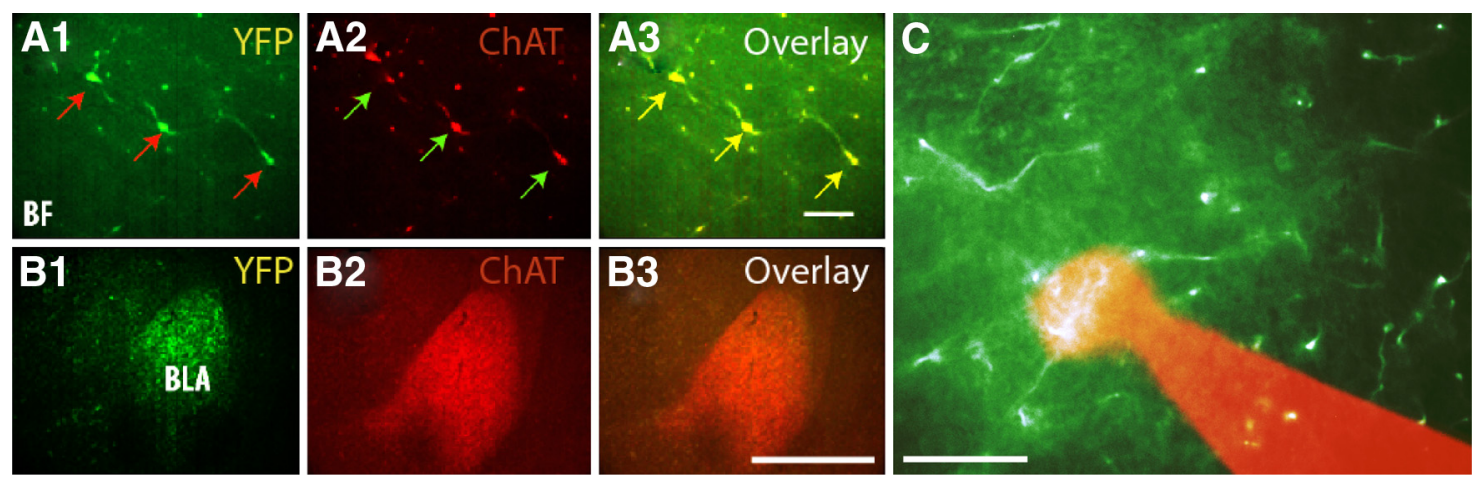

Figure 1. Correspondence between YFP and ChAT expression. $\boldsymbol{A}$, Basal forebrain (BF) neurons near the virus infusion site that express YFP (A1) and are immunopositive for ChAT (A2). $\boldsymbol{A 3}$, Overlay of $\boldsymbol{A}$ and $\boldsymbol{A 2}$. $\boldsymbol{A}$ 1-A3, Show the same field of view. $\boldsymbol{B}$, YFP-labeled (B1) and ChAT-immunoreactive (B2) axons in the BLA are similarly distributed. $\boldsymbol{B}$ 3, Overlay of $\boldsymbol{B}$ 1 and $\boldsymbol{B}$. B1-B3, Show same field of view. $\boldsymbol{C}$, Micropipette filled with Alexa 594 and recently patched soma surrounded by YFP-labeled axons. Scale bars: $A 1-A 3,100 \mu \mathrm{m} ; \boldsymbol{B} 1-B 3,1 \mathrm{~mm} ; \boldsymbol{C}, 15 \mu \mathrm{m}$.

$0.01 \mathrm{~m}$ PBS four times for $10 \mathrm{~min}$ each. Subsequently, the slices were left for overnight incubation in avidin-biotinylated horseradish peroxidase (ABC 1:100 on PB-0.3\% Triton X-100) at room temperature. On the next day, the slices were washed in $0.1 \mathrm{~m}$ PBS twice for $10 \mathrm{~min}$ each. Then, the slices were incubated in Ni-DAB for 3-10 min ( $2 \mathrm{ml}$ of $1 \%$ nickel ammonium sulfate in TBS, $2 \mathrm{ml}$ of $1 \%$ ammonium chloride in TBS, TBS $\mathrm{pH}$ 7.60 up to $50 \mathrm{ml}, 1 \mathrm{ml}$ of $20 \mathrm{mg} / \mathrm{ml}$ DAB Stock; $20 \mu \mathrm{l} / \mathrm{ml}$ of $0.03 \%$ hydrogen peroxide), air dried overnight, and coverslipped using DEPEX.

Immunohistochemistry for ChAT. Animals were deeply anesthetized with urethane $(>1.2 \mathrm{~g} / \mathrm{kg})$ and then transcardially perfused with saline followed by $4 \%$ paraformaldehyde in $0.1 \mathrm{M}$ PB. The brain was removed and placed into the same solution for overnight fixation. The next day, the brains were placed into a sucrose solution (30\%). Three days later, 50 - $\mu \mathrm{m}$-thick sections were cut using a freezing microtome. Sections were placed into $0.1 \mathrm{M} \mathrm{PB}$ for $\sim 24 \mathrm{~h}$. Every third section was taken for immunohistochemistry. Sections were washed three times in $0.1 \mathrm{M} \mathrm{PB}$ and incubated with goat-anti-ChAT (1:500; Millipore) antibody with $1 \%$ normal donkey serum and $0.5 \%$ Triton-X in $0.1 \mathrm{M} \mathrm{PB}$ for overnight incubation at room temperature under dark. The next day, sections were washed three times in $0.1 \mathrm{M} \mathrm{PB}$ and transferred into donkey-anti-Goat Cy3 IgG (1:100) with $1 \%$ normal donkey serum and $0.5 \%$ Triton-X in 0.1 M PB for $\sim 3 \mathrm{~h}$ at room temperature under dark. Finally, sections were washed three times in $0.1 \mathrm{M} \mathrm{PB}$ and mounted using Vectashield wet mounting medium.

Identification of principal cells and local-circuit neurons. Prior studies that correlated the physiological and morphological properties of BLA neurons have revealed that principal neurons come in two main varieties (for review, see Sah et al., 2003; Spampanato et al., 2011; Duvarci and Pare, 2014): regular spiking and, less frequently, intrinsically bursting. This is in contrast to most interneurons that show a fast-spiking behavior with little spike frequency adaptation and generate much briefer spikes than principal cells. However, other firing patterns have been observed in interneurons (Rainnie et al., 2006; Woodruff and Sah, 2007; Jasnow et al., 2009; Sosulina et al., 2010). Therefore, lack of fast-spiking pattern does not necessarily mean the recorded cell is not an interneuron. Consequently, we relied on morphological criteria to distinguish principal cells and interneurons (McDonald, 1992). Principal cells were identified as such by their high density of dendritic spines. Neurons that were aspiny or sparsely spiny were classified as interneurons.

\section{Results}

Correspondence between YFP-labeled and ChAT elements Previously, it was reported that the BLA contains a very high concentration of ChAT-immunopositive axons (Carlsen and Heimer, 1986; Nitecka and Frotscher, 1989; Kitt et al., 1994) and that BFc neurons contribute this dense cholinergic innervation (Woolf et al., 1983; Carlsen et al., 1985; Nitecka and Frotscher, 1989). Therefore, we first verified whether YFP-expressing BFC neurons at the virus infusion site were also immunoreactive for
ChAT. As shown in Figure $1 A$, a perfect correspondence was found between YFP and ChAT-expressing BFc neurons. That is, all YFP-expressing basal forebrain neurons were also ChAT immunoreactive.

In addition, we examined whether the distribution of YFP-labeled axons in the amygdala matched that of ChAT-immunopositive axons. As shown in Figure $1 B$, a close correspondence was found between the two. Similar to the distribution of ChAT-immunopositive fibers (Fig. 1B2), a much higher concentration of YFP-labeled axons was seen in the BLA than the central and medial nuclei (Fig. 1B1), in keeping with prior descriptions (Carlsen and Heimer, 1986; Kitt et al., 1994).

\section{Database}

We obtained patch recordings of BLA neurons and examined the impact of BFc inputs, when activated by brief $(5 \mathrm{~ms})$ pulses of blue light. To minimize the possibility of false negatives, we only recorded neurons located in a dense plexus of YFP-labeled axons (Fig. 1C). Consistent with the fact that principal cells account for the majority of BLA neurons (McDonald, 1992), most of our recordings were obtained from this cell type $(n=67 ; 51$ in wholecell mode; 16 in perforated-patch mode). These recordings were obtained from 31 mice. Typically two to three whole-cell recordings or one to two perforated-patch recordings were obtained per animal. Only one neuron was recorded per slice.

In addition, a minority of recordings was obtained from aspiny neurons presumed to be local-circuit cells: fast-spiking (FS) neurons $(n=6$; Fig. $2 A 1, A 2)$ and late-firing (LF) cells $(n=$ 5; Fig. $2 B 1, B 2)$. We begin with a description of the results obtained in these rare cell types. The rest of the Results section will be devoted to principal cells (Figs. 3-6).

\section{Physiological properties and BFc responsiveness of LF and FS interneurons}

Consistent with prior findings (Spampanato et al., 2011; Mańko et al., 2012), the temporal dynamics of current-evoked spiking were strikingly different in FS (Fig. 2A2) and LF (Fig. 2B2) neurons. In response to juxta-threshold depolarizing current pulses from rest, LF cells displayed a conspicuous delay to firing (Fig. $2 B 2$, middle), which diminished as the amplitude of the current pulse was increased (Fig. 2B2, top). In contrast, FS cells showed little delay to firing in the same testing conditions (Fig. 2A2, middle) and they could sustain high firing rates with little or no spike frequency accommodation (Fig. 2A2, top). An additional distinguishing feature was the duration of their action potentials 


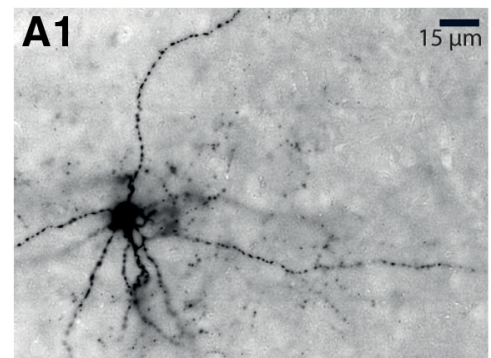

A2

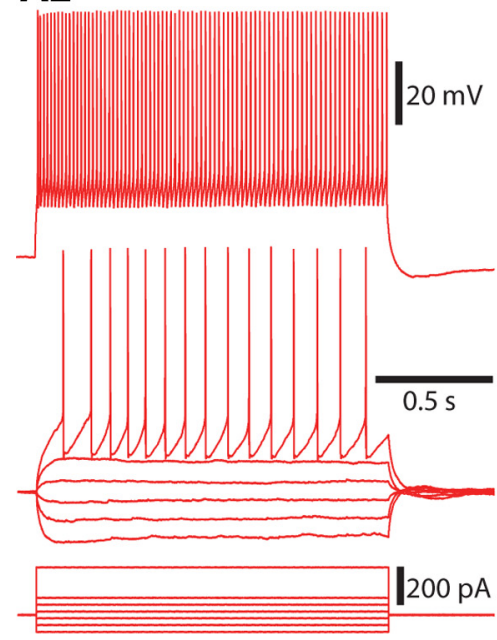

A3

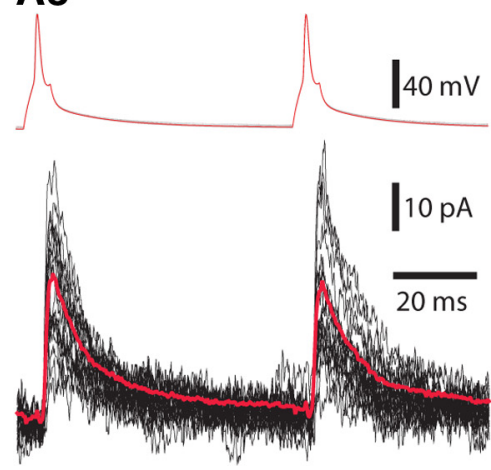

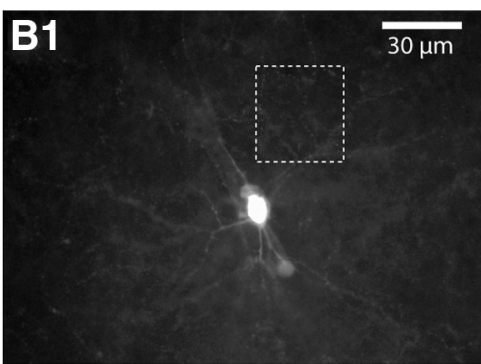

B2

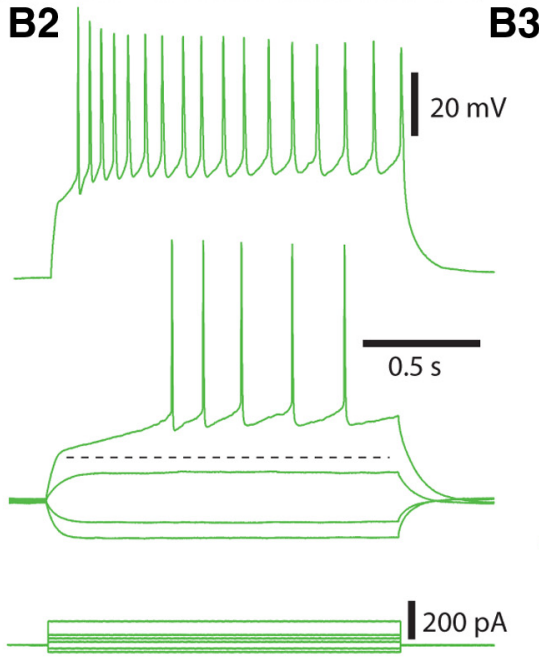

B3
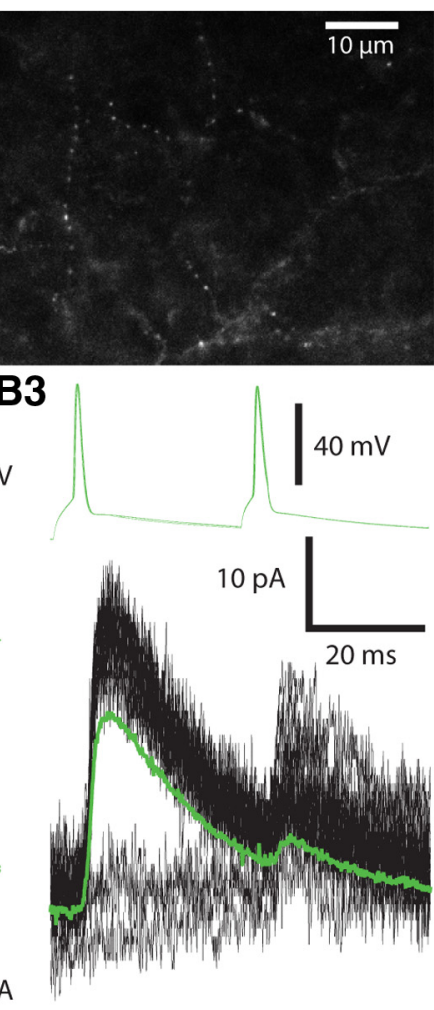

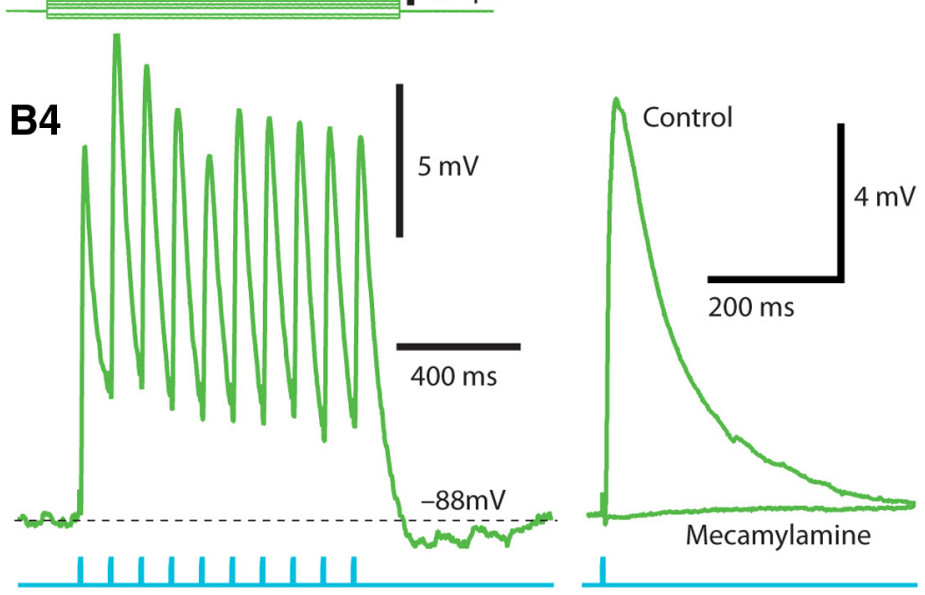

Figure 2. Contrasting physiological properties and BFc responsiveness of FS and LF neurons. Representative FS $(\boldsymbol{A})$ and LF $(\boldsymbol{B})$ neurons. Morphological properties of FS cell ( $\boldsymbol{A}$ 1) revealed with post hocvisualization of biocytin and LF neuron (B1) with Alexa 594. Region enclosed in rectangle in B1 is expanded on the right. $\boldsymbol{A 2}$, B2, Voltage responses to current pulses in FS and LF cells, respectively. FS cell can fire action potentials at high rates with little frequency accommodation. LF cell displays conspicuous delay to firing and spike-frequency accommodation. $A 3, B 3$, Paired recordings of $F S$ (A3) or LF (B3) cell (current-clamp mode, top) with a principal neuron (voltage-clamp mode, bottom; holding potential $-50 \mathrm{mV}$ ) reveal that both interneurons form GABAergic synapses with principal cells. Colored traces are the average of the black traces. B4, Left, Light-induced activation of BFc axons elicits nicotinic EPSPs in LF cell. Right, BFc-evoked EPSP is abolished by mecamylamine $(10 \mu \mathrm{M})$.

(measured at half-amplitude: LF, $1.93 \pm 0.08 \mathrm{~ms} ; \mathrm{FS}, 0.71 \pm 0.08$ $\mathrm{ms} ; t$ test, $p<0.0001)$.

In a few instances, we tested whether LF and FS cells were indeed GABAergic by obtaining simultaneous recordings of synaptically coupled principal cells located in their immediate vicinity. The principal cells were recorded in voltage-clamp mode at a holding potential of $-50 \mathrm{mV}$. Spiking in FS (Fig. 2A3) or LF (Fig. $2 B 3)$ cells elicited IPSCs in principal cells $(n=8)$, confirming that these two cell types are GABAergic interneurons.

Paralleling the differing physiological properties of LF and FS cells, photic activation of BFc inputs produced contrasting effects in these two cell types. Indeed, whereas BFc inputs elicited no detectable response in FS cells, LF neurons exhibited robust
EPSPs (Fig. 2B4; $10.9 \pm 1.5 \mathrm{mV}$ from rest) whose latencies ranged between 8 and $11 \mathrm{~ms}$. Consistent with a mediation by nicotinic receptors, these EPSPs had an extrapolated reversal potential near $0 \mathrm{mV}$ and were blocked by application of the nicotinic receptor antagonist mecamylamine $(10 \mu \mathrm{M}, n=4$; Fig. 2B4, right $)$.

\section{Impact of BFc inputs on principal cells}

Principal BLA neurons could be easily distinguished from interneurons based on the dynamics of current-evoked firing and morphology. Indeed, principal cells displayed spike frequency accommodation (Fig. 3A) and their dendrites were densely covered with spines (Fig. $3 B$ ). The latter property could be observed 


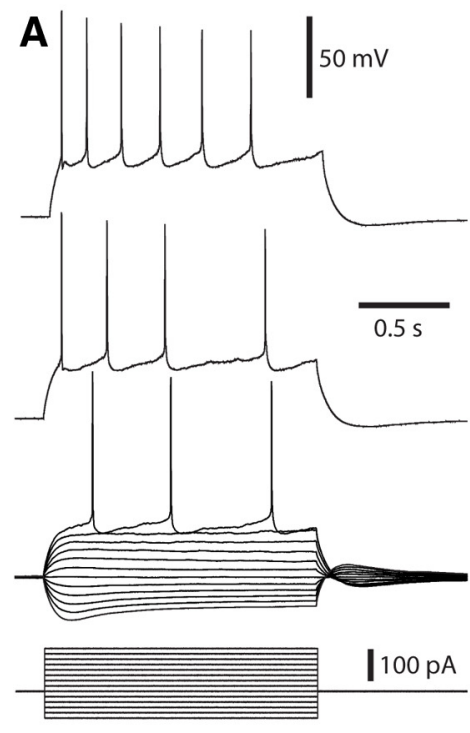

C1

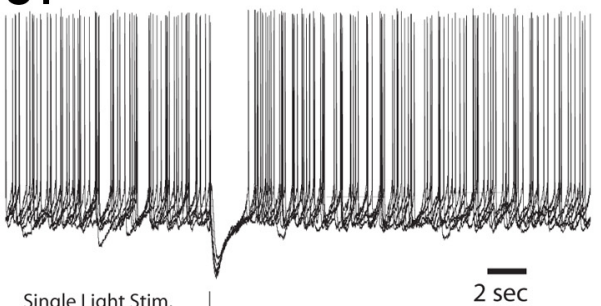

C2

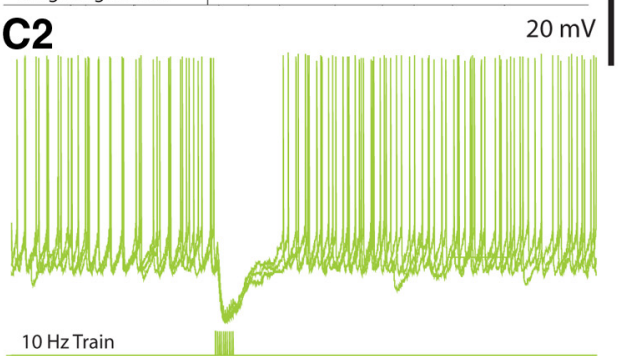

B1
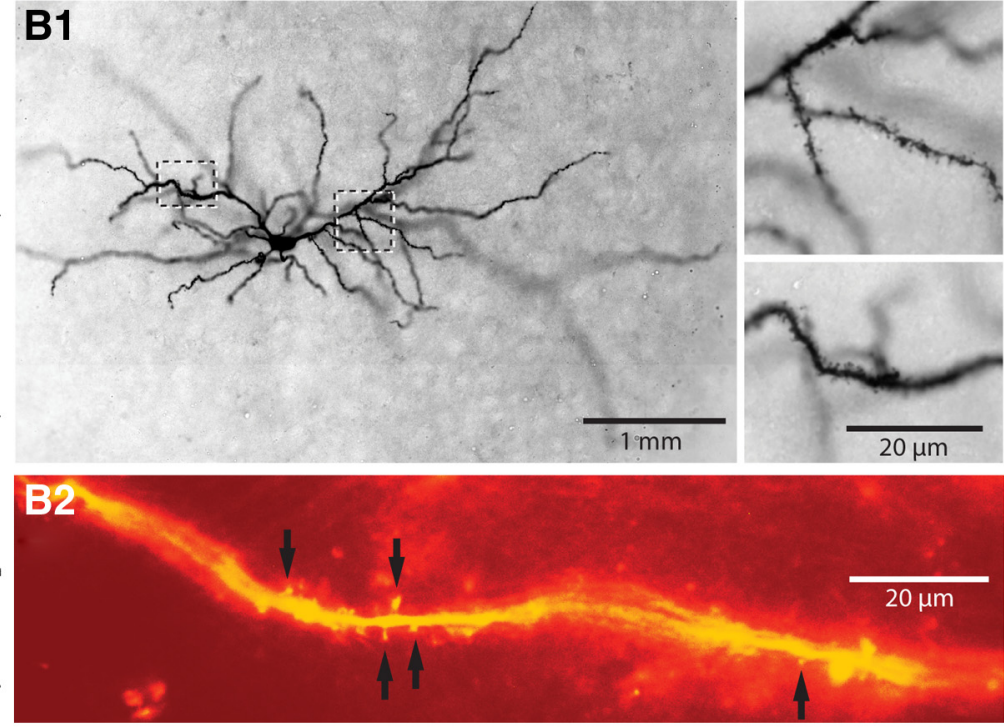

D

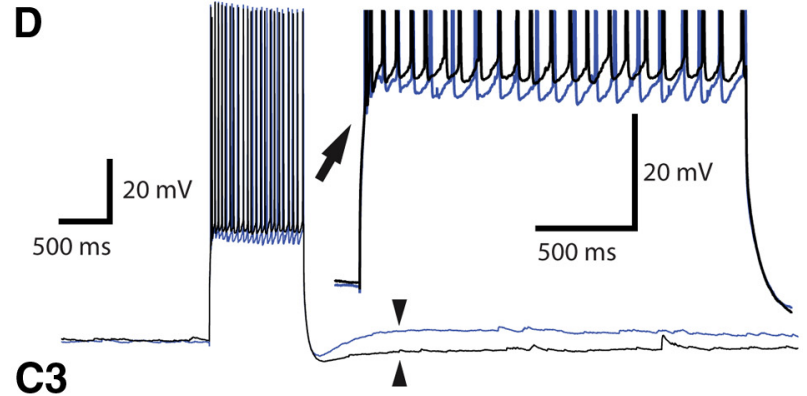

C3

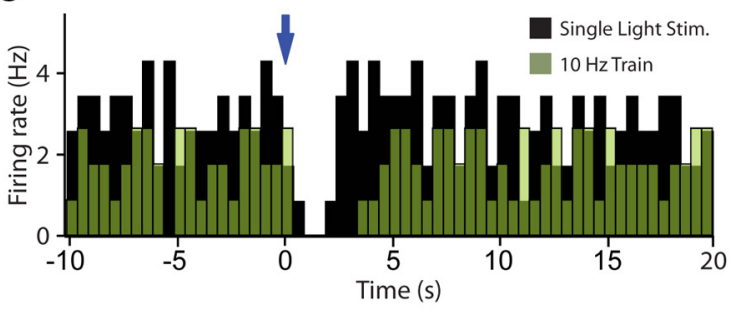

Figure 3. Responses of principal BLA neurons to BFc inputs. $\boldsymbol{A}$, Voltage response of principal BLA neuron (top) to current pulses of gradually increasing amplitude (bottom). $\boldsymbol{B}$, Morphological properties of two principal BLA neurons as identified post hoc with biocytin (B1) or during the experiment with Alexa 594 (B2). Regions enclosed in dashed lines in $\boldsymbol{B} 1$ are expanded on the right. $\boldsymbol{C}$, Effect of BFc inputs on principal BLA neuron firing tonically at $2-4 \mathrm{~Hz}$ due to a steady depolarizing current ( $60 \mathrm{pA})$. Light-induced activation of BFc inputs causes an IPSP and associated firing pause (C1, single 5 ms light stimulus, 6 superimposed trials; (2, 1.5 s train of 5 ms light stimuli at $10 \mathrm{~Hz}, 6$ superimposed trials). (3, Peristimulus histogram of neuronal discharges (black and green bars correspond to $\mathbf{C}$ and $\mathbf{C}$, respectively). The $10 \mathrm{~Hz}$ train (green) elicits a longer firing pause than the single light stimulus (black). D, Principal BLA neuron made to fire at a high rate by current injection in the absence (black) or presence (blue) of BFc inputs ( $10 \mathrm{~Hz}$ train of $5 \mathrm{~ms}$ light stimuli for the duration of the current pulse). At the end of the current pulse, a long-lasting ADP (arrowheads) is observed.

with post hoc biocytin revelation (Fig. 3B1) and during the recordings with Alexa 594 (Fig. 3B2).

We investigated the effects of BFc inputs on principal cells in two activity regimes: during quiescence (hereafter termed subthreshold effects) or when current injection elicited sustained firing (hereafter termed suprathreshold effects). Unexpectedly, light-induced activation of BFc inputs produced effects of opposite polarity in these two conditions. At rest, the predominant response was a long-lasting hyperpolarization $(0.48 \pm 0.06 \mathrm{~s}, n=$ 67; Fig. 3C1). When the cells were made to fire at modest rates $(<8 \mathrm{~Hz})$ by injection of steady depolarizing current, activation of $\mathrm{BFc}$ inputs transiently silenced the cells (Fig. $3 C$ ) and the duration of this pause increased with the duration of the light stimulus (one light pulse, $2.48 \pm 0.18 \mathrm{~s}$; Fig. $3 C 1, C 3 ; 1.5 \mathrm{~s}$ light pulse train at $10 \mathrm{~Hz}, 4.07 \pm 0.24 \mathrm{~s}$; Fig. $3 C 2, C 3$; paired $t$ test, $p=0.01)$. In contrast, when the cells were strongly activated by current injec- tion (firing rate $>8 \mathrm{~Hz}$ ), the light stimuli had a marginal effect on their firing rate during the current pulse but produced prolonged ADPs (Fig. 3D). The contrasting effects of BFc inputs in these two activity regimes are considered in detail below, first using wholecell and then perforated patch recordings. Figure 4 presents population analyses that contrast the results obtained with these two recording configurations. Unless otherwise indicated, we used single $5 \mathrm{~ms}$ pulses of blue light to analyze the impact of BFc inputs in the subthreshold regime and $1.5 \mathrm{~s}$ trains of light stimuli (each 5 ms long, delivered at $10 \mathrm{~Hz}$ ) for the suprathreshold regime.

\section{Subthreshold effects}

In the subthreshold regime, our analyses revealed that the BFcevoked inhibition was in fact comprised of two distinct components that peaked at different times, reversed at different potentials, and exhibited a contrasting pharmacological sensitiv- 

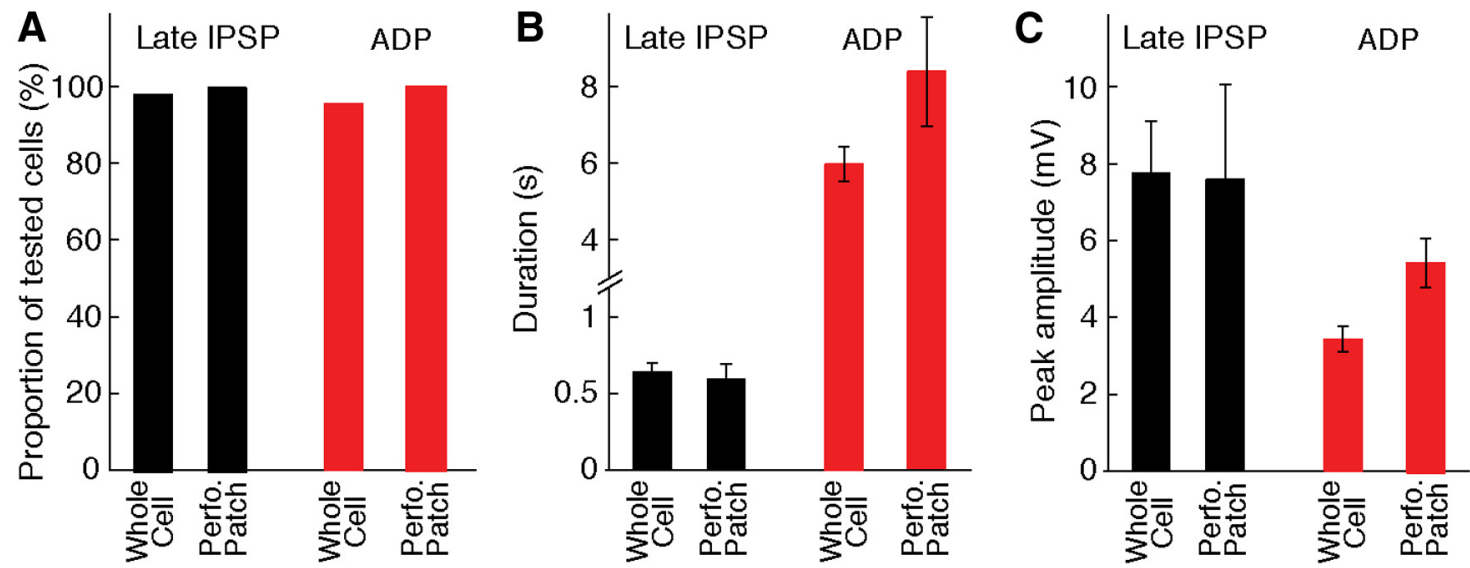

Figure 4. Incidence and properties of optically evoked cholinergic IPSPs and ADPs. A, Proportion of recorded cells in which optical activation of BFc axons elicited a late IPSP (black) or ADP (red) using the whole-cell $(n=51)$ or perforated-patch recording $(n=16)$ methods. $\boldsymbol{B}$, Duration and amplitude $(\boldsymbol{C})$ of BFc-evoked late IPSPs (black) or ADPs (red) using the whole-cell or perforated-patch recording method (averages \pm SEM). ADP amplitudes were significantly higher with the perforated-patch method ( $t$ test, $p=0.008$ ). Otherwise, the two recording methods yielded similar results for both ADPs and late IPSPS.
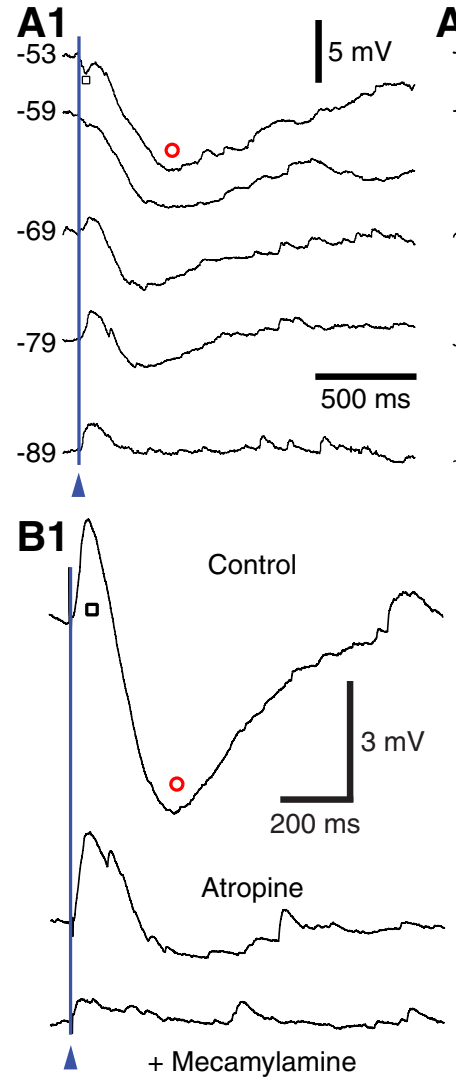

A2

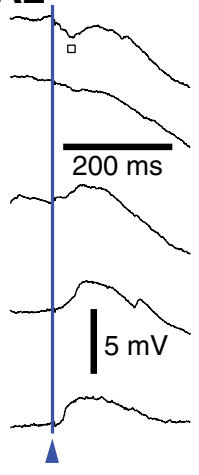

B2

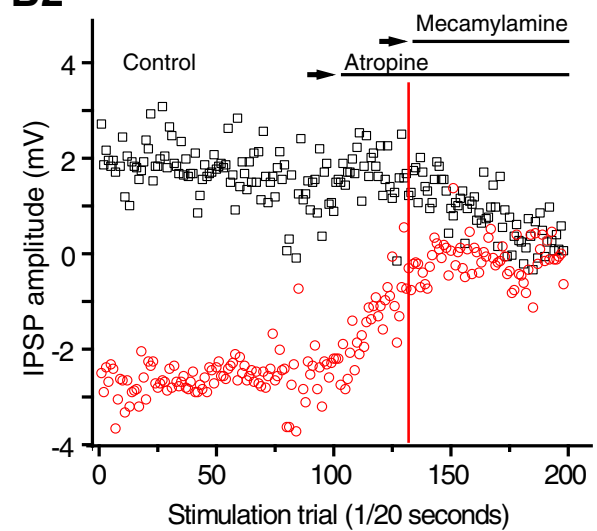

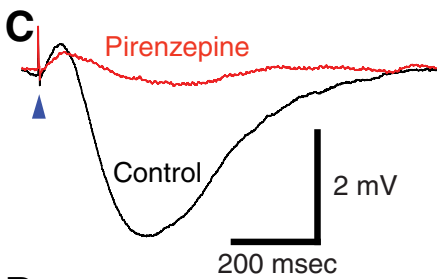

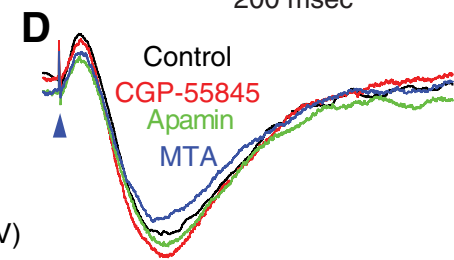

E

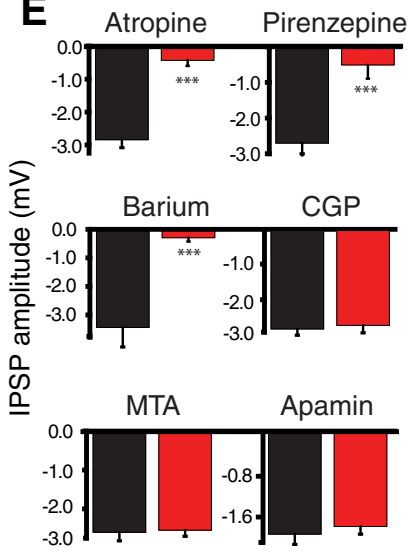

Figure 5. Mechanisms underlying inhibitory response of principal neurons to BFcinputs. $\boldsymbol{A}-\boldsymbol{D}$, Four different principal BLA neurons. $\boldsymbol{A}$, Light-induced activation of BFc inputs (blue line, $5 \mathrm{~ms}$ pulse) elicits an IPSP comprised of two components: an early one, marked by a black square, and late one, marked by a red circle. The early component is shown with an expanded time base in $\mathbf{A 2}$. As the prestimulus membrane potential is modified (numbers on the left), the early component (square) reverses at a more depolarized potential than the late component $(\boldsymbol{A B})$. $\boldsymbol{B} 1$, BFc-evoked late IPSP (top, control) is largely reduced by atropine (middle) whereas the early IPSP (reversed) is sensitive to mecamylamine (bottom). B2, Amplitude of early (black) and late (red) IPSPs (y-axis) plotted as a function of time ( $x$-axis) in control conditions, in the presence of atropine (middle) or atropine and mecamylamine (right). Same cell as in B1. C, Late IPSP component is nearly abolished by pirenzepine. D, Late IPSP is not significantly affected by CGP-55845, apamin, or MTA. E, Average ( \pm SEM) amplitude of BFc-evoked late IPSP in control conditions (black) and in the presence of various drugs. Significant reductions are marked by asterisks (paired $t$ tests, $p \leq 0.001$ ).

ity (Fig. 5). Indeed, activation of BFc inputs first elicited an early IPSP (Fig. 5A, square; latency to peak, $36.9 \pm 3.1 \mathrm{~ms}$; onset latencies, $16-20 \mathrm{~ms})$ of short duration $(40.1 \pm 2.4 \mathrm{~ms})$ that reversed in polarity positive to $-70 \mathrm{mV}$ (Fig. $5 \mathrm{A3} ;-57.6 \pm 3.7 \mathrm{mV}$ ), close to the theoretical $\mathrm{Cl}^{-}$reversal potential with our recording solu- tions. This early component was followed by an IPSP of higher amplitude (Fig. $5 A$, circle; $7.7 \pm 1.6 \mathrm{mV}$ from $-55 \mathrm{mV}$ ) and duration $(0.68 \pm 0.09 \mathrm{~s})$ that reversed negative to $-85 \mathrm{mV}$ (Fig. $5 A 3)$. It should be noted that no washout of the late IPSP was noticed during whole-cell recordings (Fig. 5B2). Thus, results 

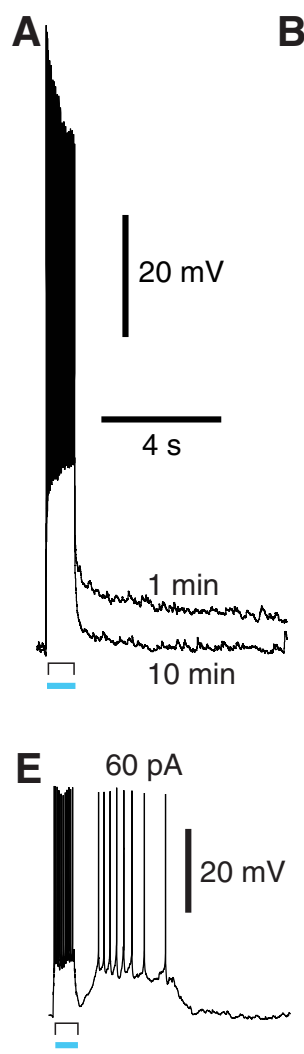
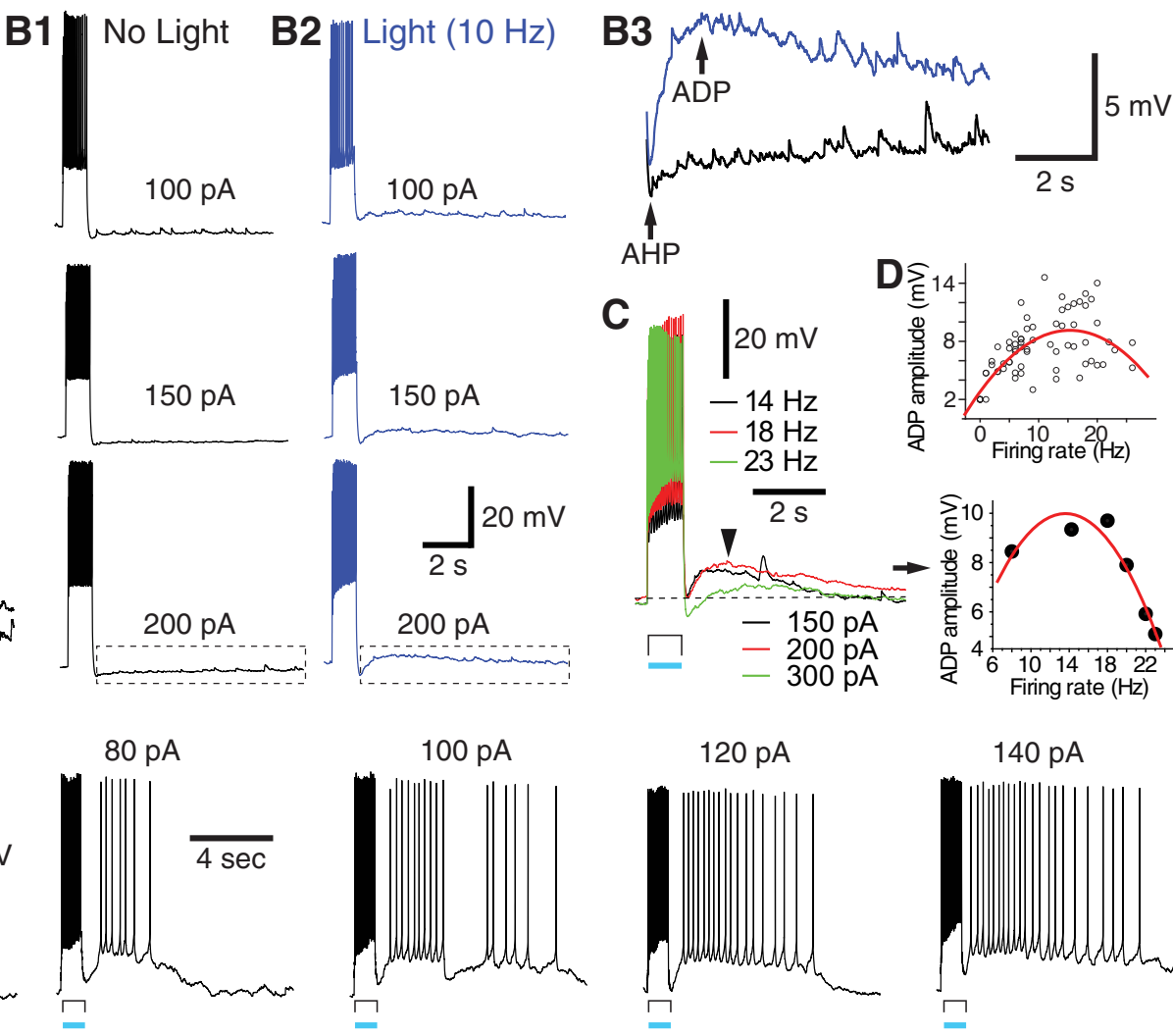

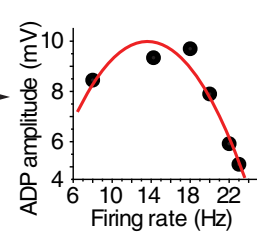

$140 \mathrm{pA}$
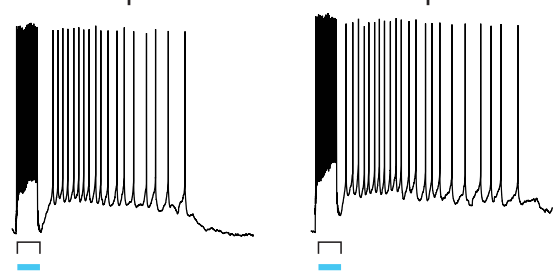

Figure 6. Properties of BFc-evoked ADP. A, Conventional patch recording. Response of BLA neuron to same depolarizing current pulse applied from rest (-65 mV), $1 \mathrm{~min}$, or $10 \mathrm{~min}$ after recording onset. Note nearly complete disappearance of ADP at the later time point. Apamin (100 nM) was present throughout. $\boldsymbol{B}-\boldsymbol{E}$, Different BLA neurons recorded with the perforated-patch method. $\boldsymbol{B}$, Response of the same BLA neuron to depolarizing current pulses of gradually increasing amplitude in the absence $(\boldsymbol{B} \mathbf{1}$, black) or presence ( $\boldsymbol{B} 2$, blue) of blue light ( $10 \mathrm{~Hz}$ train of $5 \mathrm{~ms}$ stimuli during current pulse). ADP is only present with light stimuli. B3, Expanded overlay (200 pA current pulse). C, Variations in ADP amplitude as a function of firing rate during depolarizing current pulse. Left, Three superimposed trials with current pulses of different amplitudes (color coded). Right, ADP amplitude ( $y$-axis) as a function of firing frequency ( $x$-axis) during current pulses for cell shown on the left. $\boldsymbol{D}, \mathrm{ADP}$ amplitude ( $y$-axis) as a function of firing frequency $(x$-axis) during depolarizing current pulses for all cells recorded with the perforated-patch method. $\boldsymbol{E}$, ADP elicits firing when depolarizing current pulses are applied from $-60 \mathrm{mV}$. From left to right, current pulse amplitude increases in steps of $20 \mathrm{pA}$ from 60 to $140 \mathrm{pA}$.

obtained in the whole-cell $(n=51)$ and perforated-patch recording $(n=16)$ modes are pooled below.

Paralleling their contrasting time course and voltage dependence, the two components exhibited a differential sensitivity to nicotinic and muscarinic receptor antagonists (Fig. $5 B-E$ ). Indeed, the early IPSP was insensitive to atropine $(1.5 \mu \mathrm{M} ; n=10)$, but was largely reduced by mecamylamine $(10 \mu \mathrm{M} ; n=3$; Fig. $5 B)$ and picrotoxin $(100 \mu \mathrm{M} ; n=5)$. Conversely, the late IPSP was nearly abolished by atropine (Fig. $5 B ; n=10, t=-3.72$, $p<$ 0.001 ) and the $\mathrm{M} 1$ receptor antagonist pirenzepine (Fig. 5C,E; 1 $\mu \mathrm{M}, n=4 ; t=-15.73, p<0.01)$, but it persisted in the presence of the M2 receptor antagonist methoctramine (MTA; Fig. 5D, E; $1 \mu \mathrm{M}, n=3)$.

The late IPSP was also largely reduced by the inwardly rectifying $\mathrm{K}^{+}$conductance blocker barium (Fig. $5 E ; n=5, t=7.94$, $p<0.001)$, but was insensitive to picrotoxin $(100 \mu \mathrm{m}, n=5)$ and the GABA-B antagonist CGP-55845 (Fig. 5D; $10 \mu \mathrm{M}, n=5$ ), as well as ionotropic glutamate receptor antagonists (CNQX, 20 $\mu \mathrm{M} ; \mathrm{AP}-5,100 \mu \mathrm{M} ; n=10)$. Because a prior study reported that muscarinic receptor activation could elicit an IPSP in principal cells via the activation of SK channels secondary to $\mathrm{Ca}^{2+}$ release from intracellular stores (Power and Sah, 2008), we tested whether the late IPSP was sensitive to the SK antagonist apamin. It was not (Fig. $5 D, E ; 100 \mathrm{nM}, n=3$ ). However, we note that in this prior study, the IPSP developed when the muscarinic agonist was applied while firing the cells (Power and Sah, 2008).
These results suggest that in principal BLA neurons at rest, BFc inputs exert an inhibitory effect. This inhibition is comprised of two phases. The first component is likely mediated by the nicotinic activation of GABAergic local-circuit cells, possibly LF cells (Fig. 2B4), which then elicit GABA-A IPSPs in principal neurons. This is supported by the sensitivity of the early IPSPs to mecamylamine and picrotoxin and the fact that the IPSP latency in principal cells $(\sim 18 \mathrm{~ms})$ was longer than that of the nicotinic EPSPs in LF cells $(\sim 10 \mathrm{~ms})$. In contrast, the second component results from the direct activation of M1 receptors on principal cells and the consequent activation of an inwardly rectifying $\mathrm{K}^{+}$ conductance.

Finally, we sought to determine whether longer lasting stimulation protocols $(8-20 \mathrm{~s}$ trains of light pulses at $4-20 \mathrm{~Hz})$ would elicit the slow excitation previously observed in pharmacological experiments (Cole and Nicoll, 1984; Benson, 1988). While the muscarinic IPSP was observed in all principal cells tested with this stimulation protocol $(n=6)$, no depolarization could be observed, even when the cells were tonically depolarized just below spike threshold with DC current injection.

\section{Suprathreshold effects}

We first describe the main properties of the ADPs and then consider their pharmacological sensitivity. From rest, ADPs could be elicited in all tested principal cells by pairing suprathreshold intracellular current injections with cholinergic stimulation $(n=$ 64; $10 \mathrm{~Hz}$ train of $5 \mathrm{~ms}$ blue light pulses for the duration of the 
current injection). In these conditions, ADP amplitudes and durations were variable, ranging between 2 and $14 \mathrm{mV}$ and 7-10 s, respectively (Figs. $1 D, 6,7$ ). Importantly, in whole-cell recording mode, ADP amplitudes decreased rapidly with time $(50-85 \%$ reduction in $10 \mathrm{~min}$; Fig. $6 A)$. Thus, the following analyses are based on perforated-patch recordings of principal cells $(n=16)$. In these conditions, peak ADP amplitudes and durations averaged $5.1 \pm 3.3 \mathrm{mV}$ and $8.3 \pm$ $2.9 \mathrm{~s}$, respectively.

ADPs could not be elicited in the absence of cholinergic stimulation, no matter how much depolarizing current was injected (Fig. 6B1). They were only seen with concurrent current-evoked firing and BFc stimulation (Fig. 6B2). Conversely, when cholinergic stimulation was applied in the absence of suprathreshold depolarizing current injection, no depolarization was seen. Also, ADP amplitudes did not vary linearly with the amount of depolarizing current injected or with firing frequency (Fig. 6C,D). Instead, we observed an inverted $U$ relationship such that ADP amplitudes grew when current-evoked firing rates increased up to $\sim 10-18 \mathrm{~Hz}$ and then decreased with further increases in discharge rates (Fig. $6 D$; polynomial fit with two terms; $p=$ 0.0092 and $p=0.019$ ). Finally, while ADPs generally did not trigger spikes when elicited from rest ( 2 of 16 cells), they always did when the prepulse potential was set positive to $-60 \mathrm{mV}$ by intracellular current injection (Fig. 6E).

The pharmacological sensitivity of ADPs was investigated in the presence of CNQX $(20 \mu \mathrm{M}), \mathrm{AP}-5(100 \mu \mathrm{M})$, and picrotoxin $(100 \mu \mathrm{M})$. As shown in Figure 7, ADPs were sensitive to the nonselective muscarinic receptor antagonist atropine $(1 \mu \mathrm{M} ; n=5$; Fig. $7 A)$, the selective $\mathrm{M} 1$ receptor antagonist pirenzepine $(1 \mu \mathrm{M}$; $n=5$; Fig. $7 B)$, and the $I_{\mathrm{CAN}}\left(\mathrm{Ca}^{2+}\right.$-activated nonselective cation channel) blocker flufenamic acid (100 $\mu \mathrm{M} ; n=5$; Fig. 7C). In contrast, the M2 receptor antagonist MTA ( $1 \mu \mathrm{M})$ had no effect $(n=3)$. In light of prior findings (Yajeya et al., 1997, 1999; Haj-Dahmane and Andrade, 1999; Egorov et al., 2006), these results suggest that ADPs are mediated through the activation of $I_{\text {CAN }}$ secondary to $\mathrm{M} 1$ receptor signaling during endogenous ACh release.

\section{Effect of local pressure application of carbachol}

It is possible that the discrepancy between the cholinergic effects observed here and prior pharmacological studies is not due to differences between the stimulation methods but to the particular mouse strain or experimental conditions we used. To determine whether this was the case, in the same conditions and mice as above, we examined the effects of CCh $(3 \mu \mathrm{M}$ or $10 \mu \mathrm{M})$ in 23 principal BL neurons in the presence of CNQX $(20 \mu \mathrm{M}), \mathrm{AP}-5$ $(100 \mu \mathrm{M})$, and picrotoxin $(100 \mu \mathrm{M})$. CCh was either added to the perfusate $(n=10)$ or delivered by local pressure application $(n=13)$.

As mentioned above and documented in Figure 4, using optogenetic methods, the muscarinic IPSP and ADPs were seen in
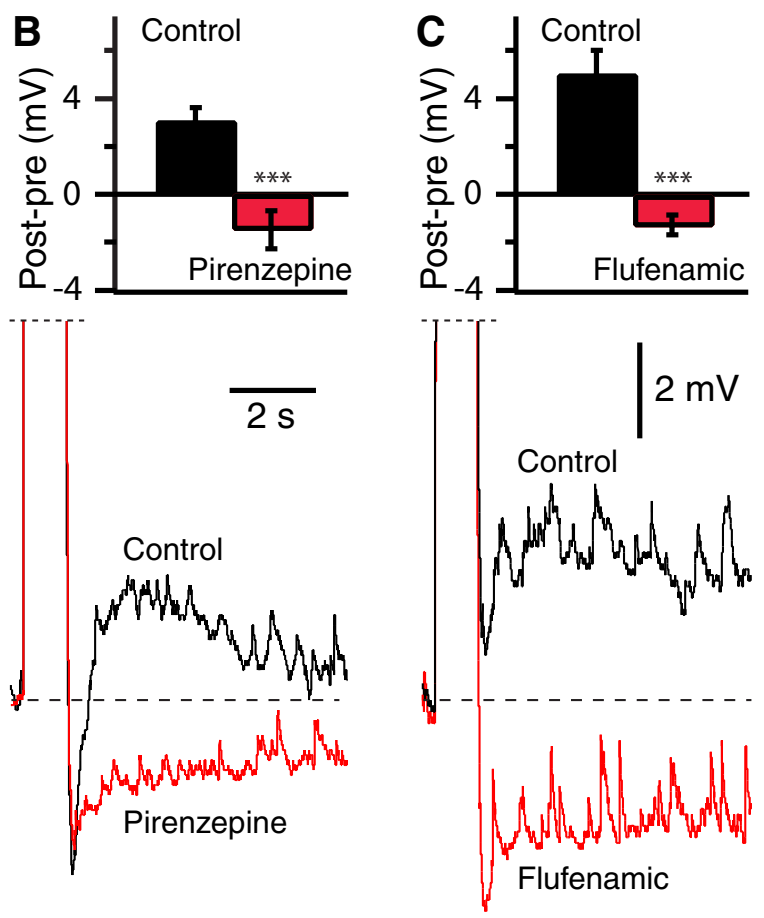

Pharmacological sensitivity of BFc-evoked ADP. A-C, Top, Grouped data indicating means ( \pm SEM). Bottom, Indi(n) all cases, black indicates control response with light stimulus in the absence of drug. Red indicates response pirenzepine $(\boldsymbol{B} ; 1 \mu \mathrm{M})$, and flufenamic acid $(\boldsymbol{C} ; 100 \mu \mathrm{m})$. ADP was measured as voltage difference between peak voltage within $4 \mathrm{~s}$ of current pulse offset and prepulse value. Significant reductions are marked by asterisks (paired $t$ tests, $p \leq 0.001$ ).

virtually all tested cells ( $\geq 96 \%$ ). In contrast, using either pressure application of CCh or addition of the drug to the perfusate, muscarinic IPSPs were never observed. A representative example of response evoked by pressure-applied CCh is shown in Figure $8 A$, along with group statistics (Fig. $8 B$ ). In all tested cells and regardless of the CCh concentration ( $3 \mu \mathrm{M}$ or $10 \mu \mathrm{M}$ ) or method of drug application, CCh elicited a long-duration depolarization that was associated with an increase in input resistance. With pressureapplied CCh $(10 \mu \mathrm{M})$, we noticed that the increased input resistance outlasted the EPSP by $>1.5 \mathrm{~min}$, indicating the recruitment of several parallel mechanisms by CCh. When CCh $(10 \mu \mathrm{M})$ was applied via the perfusate, the response peaked within $13.3 \pm 1.5 \mathrm{~s}$ at $11.2 \pm 2.6 \mathrm{mV}$, and continued for as long as the CCh application persisted. Whereas pirenzepine ( $1 \mu \mathrm{M} ; n=5)$ blocked all CCh effects, flufenamic acid only reduced the EPSP by $52 \pm 15 \%$ $(n=3)$.

To rule out the possibility that the lack of CCh-evoked IPSP was due to the fact that test potentials were too hyperpolarized, in eight principal cells we injected steady depolarizing currents that elicited firing at $\sim 0.3-0.5 \mathrm{~Hz}(0.39 \pm 0.08 \mathrm{~Hz})$ and then pressure applied CCh. CCh $(10 \mu \mathrm{M})$ produced a significant increase in firing rate (to $1.15 \pm 0.16 \mathrm{~Hz}$; paired $t$ test, $p=0.002$ ), but again no IPSP.

\section{Discussion}

We investigated the influence of BFc inputs on BLA neurons using optogenetic methods. The interest of this question stems from earlier observations suggesting that ACh facilitates memory formation in BLA-dependent tasks. We found that BFc inputs exert cell type-specific effects that also depend on the state of target neurons. In particular, select subtypes of interneurons (LF but not FS cells) exhibited fast nicotinic EPSPs that led to the 
A

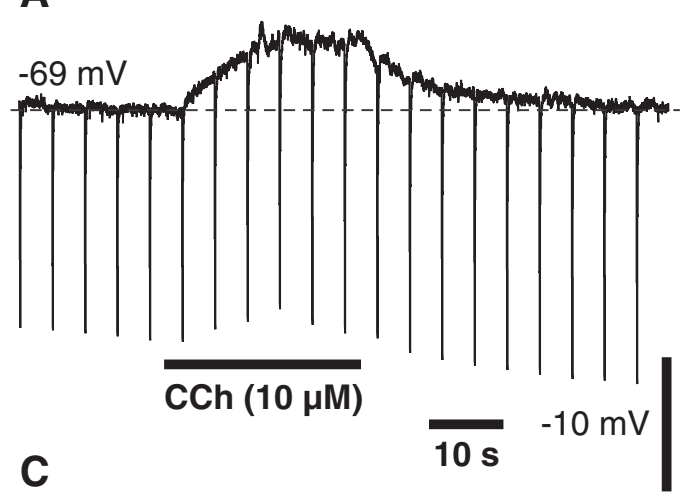

B1

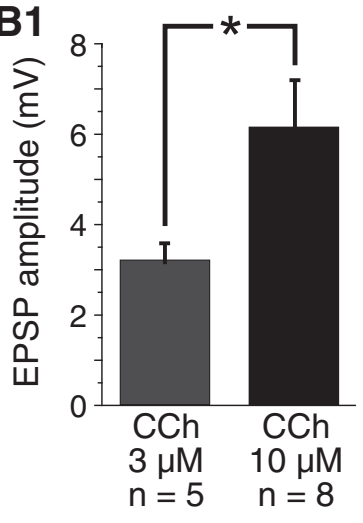

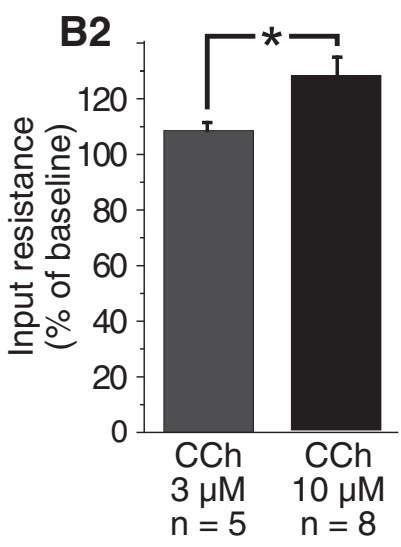

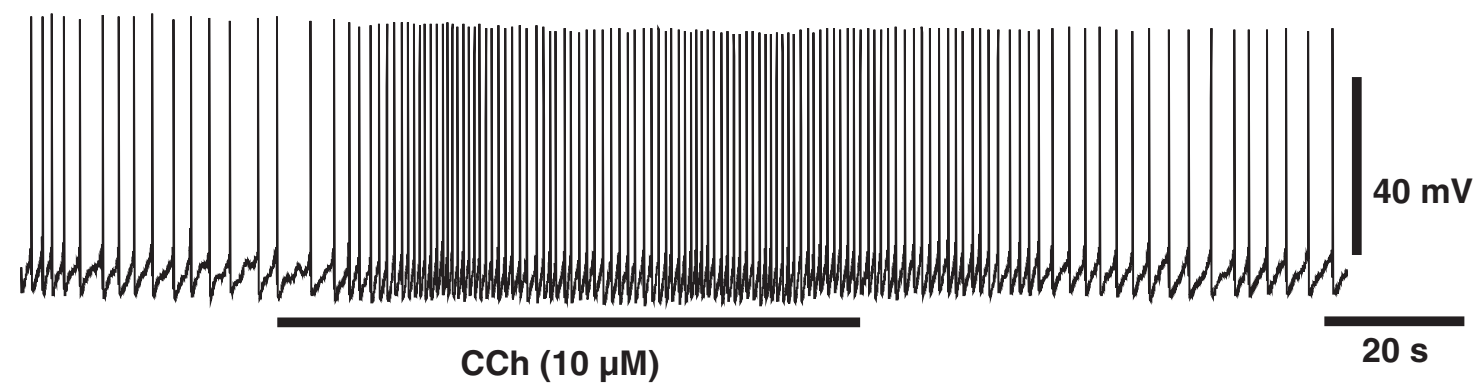

Figure 8. Effect of CCh on principal BLA neurons. All tests were performed in the presence of CNQX (20 $\mu \mathrm{M}), A P-5(100 \mu \mathrm{M})$, and picrotoxin (100 $\mu \mathrm{M})$. $A$, Pressure-applied CCh (10 $\mu \mathrm{M})$ elicits slow EPSP in principal cell at rest $(-69 \mathrm{mV})$. A negative current pulse of fixed amplitude (100 pA) was applied every $5 \mathrm{~s}$ to monitor input resistance. $\boldsymbol{B}$, Averages \pm SEM of CCh-evoked EPSP amplitudes (B1) and input resistance changes (B2) elicited by $3 \mu \mathrm{m}$ (gray) and $10 \mu \mathrm{m}$ (black) CCh. Sample sizes are indicated below. C, Principal cell made to fire by injection of steady depolarizing current (15 $\mathrm{pA})$ shows firing rate acceleration during and shortly after pressure application of $\mathrm{CCh}(10 \mu \mathrm{M})$.

generation of GABA-A IPSPs in principal cells. In addition to eliciting this rapid inhibition, BFc inputs evoked a long-lasting IPSP in principal cells, resulting from the direct activation of M1 receptors and the consequent activation of an inwardly rectifying $\mathrm{K}^{+}$conductance. In addition to these inhibitory effects, however, $\mathrm{BFc}$ inputs could excite principal cells provided they coincided with a critical level of depolarization. In these conditions, BFc inputs elicited a prolonged M1-mediated ADP. Below, we consider the significance of these findings in light of earlier work about cholinergic influences in the BLA and cortex, as well as their impact on memory formation.

\section{Prior findings on the influence of $\mathrm{ACh}$}

Most prior studies on cholinergic influences in cortex and BLA relied on prolonged applications of cholinergic agonists in vitro. Using this approach, it was generally found that cholinergic agonists produce an excitation of principal BLA (Womble and Moises, 1993; Egorov et al., 2006) and cortical (for review, see McCormick, 1993) neurons via the activation of muscarinic receptors. In the amygdala, depending on the particular study, this effect was found to depend on $\mathrm{Ca}^{2+}$ entry and the consequent activation of $I_{\text {CAN }}$ (Yajeya et al., 1997, 1999; Egorov et al., 2006) or, more commonly, on the inhibition of various $\mathrm{K}^{+}$conductances leading to the generation of slow EPSPs associated with increased input resistances (Washburn and Moises, 1992; Womble and Moises, 1992, 1993; Pape and Driesang, 1998; Faber and Sah, 2002). However, in principal amygdala (Power and Sah, 2008) and cortical (Gulledge and Stuart, 2005; Gulledge et al., 2007, 2009) neurons, it was also reported that muscarinic receptor activation could have a direct inhibitory effect via the activation of SK channels. However, this inhibitory effect was dependent on prior $\mathrm{Ca}^{2+}$ entry following neuronal spiking in amygdala neu- rons versus $\mathrm{Ca}^{2+}$ release from $\mathrm{IP}_{3}$-sensitive intracellular $\mathrm{Ca}^{2+}$ stores in cortical cells (Power and Sah, 2008).

Here, we found that optogenetic activation of BFc inputs to BLA neurons does not trigger the canonical, slow cholinergic EPSP documented in prior pharmacological studies. Moreover, the muscarinic IPSPs observed in our study did not require SK channels. Paralleling this situation, opposite conclusions were also reached regarding the cholinergic responsiveness of olfactory bulb $(\mathrm{OB})$ neurons when using pharmacological versus optogenetic methods. Indeed, Smith and Araneda (2010), using a pharmacological approach, found an increased M1 receptor-mediated excitability in granule and mitral/tufted $\mathrm{OB}$ neurons. In contrast, delivery of endogenous $\mathrm{ACh}$ with optogenetic activation of $\mathrm{BFc}$ axons in vivo completely silenced these OB neurons (Ma and Luo, 2012).

A likely explanation for these divergent results resides in the contrasting spatiotemporal profile of cholinergic receptor activation produced by adding drugs to the perfusate versus activating $\mathrm{BFc}$ axons. Indeed, whereas the former method causes a prolonged and spatially uniform concentration of cholinergic agonists, the latter leads to a transient and spatially heterogeneous rise in ACh concentration. In particular, optogenetic activation of $\mathrm{BFc}$ inputs is expected to produce regions of higher ACh concentration at proximity of cholinergic axon terminals and a lower activation of extrasynaptic receptors than the pharmacological approach. A counterargument to this proposal is the long-held position that most cholinergic synapses lack conventional postsynaptic specializations necessary for the emergence of functional ACh microdomains (Umbriaco et al., 1994; Mrzljak et al., 1995; Yamasaki et al., 2010). However, we note that other electron microscopic investigations from highly respected laboratories support the opposite view (Beaulieu and Somogyi, 1991; Turrini et al., 2001; Muller et al., 2011, 2013). 
These considerations suggest that the divergent results of pharmacological and optogenetic studies result from the fact that the former approach produces more activation of extrasynaptic receptors. Implicit in this formulation is the possibility that the downstream effectors of synaptic and extrasynaptic M1 receptors are different, a proposal that awaits experimental scrutiny.

\section{The impact of BFc inputs depends on the state of principal BLA neurons}

As observed in the present study, prior optogenetic studies in the striatum (English et al., 2012) and cortex (Arroyo et al., 2012; Bennett et al., 2012) revealed that optogenetic activation of cholinergic axons elicits nicotinic EPSPs in GABAergic interneurons, and subsequently GABA-A IPSPs in principal cells. In cortex, select subtypes of interneurons exhibit these nicotinic EPSPs (Arroyo et al., 2012): as observed here, LF cells do but FS cells do not.

However, to the best of our knowledge, prior optogenetic studies did not investigate the neuromodulatory actions of ACh produced via the activation of metabotropic receptors. Indeed, we found that in principal BLA cells, the fast GABA-A IPSPs resulting from the nicotinic activation of interneurons were followed by a prolonged IPSP that reversed near the $\mathrm{K}^{+}$equilibrium potential. These long-lasting IPSPs were sensitive to atropine, pirenzepine, and barium suggesting that they are mainly mediated by M1 receptor activation coupled to the activation of G-protein-coupled inward rectifier channels (Eggermann and Feldmeyer, 2009).

Although BFc inputs only exerted inhibitory effects in quiescent principal neurons, this was not the case when activation of $\mathrm{BFc}$ inputs was paired to strong activation of the target cells. In these conditions, the muscarinic inhibition appeared to be overwhelmed and excitation predominated. This excitation took the form of prolonged (7-10 s) ADPs, which invariably elicited firing from potentials positive to $-60 \mathrm{mV}$, but typically not from more polarized potentials. Pharmacological analyses revealed that these ADPs were dependent on M1 receptor activation and that they were sensitive to flufenamic acid. In light of prior findings in cortex (Haj-Dahmane and Andrade, 1999) and amygdala (Yajeya et al., 1997, 1999; Egorov et al., 2006), these results suggest that the BFc-evoked ADPs depend on an M1-mediated activation of $I_{\text {CAN }}$. Here, it should be noted that while a muscarinic activation of $\mathrm{I}_{\mathrm{CAN}}$ was previously reported in principal BLA neurons (Yajeya et al., 1997, 1999), in contrast to the present study, no prior depolarization was required with pharmacological activation of muscarinic receptors.

\section{Possible implication for cholinergic influences over BLA- dependent memory tasks}

As reviewed in the Introduction, much evidence indicates that cholinergic inputs to the amygdala facilitate memory formation in BLA-dependent tasks. Yet, the mechanisms underlying this effect remain unclear. The results of the present study shed new light on this question. Indeed, we observed that the impact of BFC inputs on principal cells varies depending on how strongly activated they are. Weakly activated cells are inhibited by BFc inputs whereas strongly activated neurons are further excited, in effect increasing differentiation of activity levels among principal cells. These findings integrate well into the notion of an acetylcholinemediated increase in signal/noise ratio in cortical structures, proposed earlier by other authors (Sarter et al., 2005; Giocomo and Hasselmo, 2007). Given earlier findings indicating that a form of synaptic competition governs the assignment of principal neurons to memory traces (Han et al., 2007, 2009) and evidence that disynaptic inhibition between principal cells plays a critical role in this respect (Kim et al., 2013), our results suggest that BFC inputs might be facilitating memory formation by biasing the synaptic competition in favor of the strongly activated cells. Also, because the cholinergic ADPs lengthen the effective period of excitation, they might contribute to the formation of stimulus associations during conditioning tasks where the timing of conditioned and unconditioned stimuli is not optimal for the induction of synaptic plasticity.

\section{References}

Arroyo S, Bennett C, Aziz D, Brown SP, Hestrin S (2012) Prolonged disynaptic inhibition in the cortex mediated by slow, non- $\alpha 7$ nicotinic excitation of a specific subset of cortical interneurons. J Neurosci 32:3859-3864. CrossRef Medline

Beaulieu C, Somogyi P (1991) Enrichment of cholinergic synaptic terminals on GABAergic neurons and coexistence of immunoreactive GABA and choline acetyltransferase in the same synaptic terminals in the striate cortex of the cat. J Comp Neurol 304:666-680. CrossRef Medline

Ben-Ari Y, Zigmond RE, Shute CC, Lewis PR (1977) Regional distribution of choline acetyltransferase and acetylcholinesterase within the amygdaloid complex and stria terminalis system. Brain Res 120:435-444. CrossRef Medline

Bennett C, Arroyo S, Berns D, Hestrin S (2012) Mechanisms generating dual-component nicotinic EPSCs in cortical interneurons. J Neurosci 32:17287-17296. CrossRef Medline

Benson JA (1988) Bicuculline blocks the response to acetylcholine and nicotine but not to muscarine or GABA in isolated insect neuronal somata. Brain Res 458:65-71. CrossRef Medline

Carlsen J, Heimer L (1986) A correlated light and electron microscopic immunocytochemical study of cholinergic terminals and neurons in the rat amygdaloid body with special emphasis on the basolateral amygdaloid nucleus. J Comp Neurol 244:121-136. CrossRef Medline

Carlsen J, Záborszky L, Heimer L (1985) Cholinergic projections from the basal forebrain to the basolateral amygdaloid complex: a combined retrograde fluorescent and immunohistochemical study. J Comp Neurol 234:155-167. CrossRef Medline

Cole AE, Nicoll RA (1984) Characterization of a slow cholinergic postsynaptic potential recorded in vitro from rat hippocampal pyramidal cells. J Physiol 352:173-188. Medline

Duvarci S, Pare D (2014) Amygdala microcircuits controlling learned fear. Neuron 82:966-980. CrossRef Medline

Eggermann E, Feldmeyer D (2009) Cholinergic filtering in the recurrent excitatory microcircuit of cortical layer 4. Proc Natl Acad Sci U S A 106: 11753-11758. CrossRef Medline

Egorov AV, Unsicker K, von Bohlen und Halbach O (2006) Muscarinic control of graded persistent activity in lateral amygdala neurons. Eur J Neurosci 24:3183-3194. CrossRef Medline

English DF, Ibanez-Sandoval O, Stark E, Tecuapetla F, Buzsáki G, Deisseroth K, Tepper JM, Koos T (2012) GABAergic circuits mediate the reinforcement-related signals of striatal cholinergic interneurons. Nat Neurosci 15:123-130. CrossRef Medline

Faber ES, Sah P (2002) Physiological role of calcium-activated potassium currents in the rat lateral amygdala. J Neurosci 22:1618-1628. Medline

Giocomo LM, Hasselmo ME (2007) Neuromodulation by glutamate and acetylcholine can change circuit dynamics by regulating the relative influence of afferent input and excitatory feedback. Mol Neurobiol 36:184200. CrossRef Medline

Gold PE (2003) Acetylcholine modulation of neural systems involved in learning and memory. Neurobiol Learn Mem 80:194-210. CrossRef Medline

Gulledge AT, Stuart GJ (2005) Cholinergic inhibition of neocortical pyramidal neurons. J Neurosci 25:10308-10320. CrossRef Medline

Gulledge AT, Park SB, Kawaguchi Y, Stuart GJ (2007) Heterogeneity of phasic cholinergic signaling in neocortical neurons. J Neurophysiol 97:22152229. CrossRef Medline

Gulledge AT, Bucci DJ, Zhang SS, Matsui M, Yeh HH (2009) M1 receptors mediate cholinergic modulation of excitability in neocortical pyramidal neurons. J Neurosci 29:9888-9902. CrossRef Medline

Haj-Dahmane S, Andrade R (1999) Muscarinic receptors regulate two dif- 
ferent calcium-dependent non-selective cation currents in rat prefrontal cortex. Eur J Neurosci 11:1973-1980. CrossRef Medline

Han JH, Kushner SA, Yiu AP, Cole CJ, Matynia A, Brown RA, Neve RL, Guzowski JF, Silva AJ, Josselyn SA (2007) Neuronal competition and selection during memory formation. Science 316:457-460. CrossRef Medline

Han JH, Kushner SA, Yiu AP, Hsiang HL, Buch T, Waisman A, Bontempi B, Neve RL, Frankland PW, Josselyn SA (2009) Selective erasure of a fear memory. Science 323:1492-1496. CrossRef Medline

Jasnow AM, Ressler KJ, Hammack SE, Chhatwal JP, Rainnie DG (2009) Distinct subtypes of cholecystokinin (CCK)-containing interneurons of the basolateral amygdala identified using a CCK promoter-specific lentivirus. J Neurophysiol 101:1494-1506. CrossRef Medline

Kim D, Paré D, Nair SS (2013) Assignment of model amygdala neurons to the fear memory trace depends on competitive synaptic interactions. J Neurosci 33:14354-14358. CrossRef Medline

Kitt CA, Höhmann C, Coyle JT, Price DL (1994) Cholinergic innervation of mouse forebrain structures. J Comp Neurol 341:117-129. CrossRef Medline

Krnjević K (2004) Synaptic mechanisms modulated by acetylcholine in cerebral cortex. Prog Brain Res 145:81-93. Medline

Levey AI, Kitt CA, Simonds WF, Price DL, Brann MR (1991) Identification and localization of muscarinic acetylcholine receptor proteins in brain with subtype-specific antibodies. J Neurosci 11:3218-3226. Medline

Ma M, Luo M (2012) Optogenetic activation of basal forebrain cholinergic neurons modulates neuronal excitability and sensory responses in the main olfactory bulb. J Neurosci 32:10105-10116. CrossRef Medline

Mańko M, Bienvenu TC, Dalezios Y, Capogna M (2012) Neurogliaform cells of amygdala: a source of slow phasic inhibition in the basolateral complex. J Physiol 590:5611-5627. CrossRef Medline

McCormick DA (1993) Actions of acetylcholine in the cerebral cortex and thalamus and implications for function. Prog Brain Res 98:303-308. CrossRef Medline

McDonald AJ (1992) Cell types and intrinsic connections of the amygdala. In: The amygdala: neurobiological aspects of emotion, memory, and mental dysfunction (Aggleton JP, ed), pp 67-96. New York: Wiley.

McDonald AJ, Mascagni F (2010) Neuronal localization of ml muscarinic receptor immunoreactivity in the rat basolateral amygdala. Brain Struct Funct 215:37-48. CrossRef Medline

McDonald AJ, Mascagni F (2011) Neuronal localization of M2 muscarinic receptor immunoreactivity in the rat amygdala. Neuroscience 196:49-65. CrossRef Medline

McIntyre CK, Ragozzino ME, Gold PE (1998) Intra-amygdala infusions of scopolamine impair performance on a conditioned place preference task but not a spatial radial maze task. Behav Brain Res 95:219-226. CrossRef Medline

McIntyre CK, Marriott LK, Gold PE (2003) Cooperation between memory systems: acetylcholine release in the amygdala correlates positively with performance on a hippocampus-dependent task. Behav Neurosci 117: 320-326. CrossRef Medline

Mesulam MM (2004) The cholinergic innervation of the human cerebral cortex. Prog Brain Res 145:67-78. CrossRef Medline

Metherate R, Cox CL, Ashe JH (1992) Cellular bases of neocortical activation: modulation of neural oscillations by the nucleus basalis and endogenous acetylcholine. J Neurosci 12:4701-4711. Medline

Mrzljak L, Levey AI, Goldman-Rakic PS (1993) Association of m1 and m2 muscarinic receptor proteins with asymmetric synapses in the primate cerebral cortex: morphological evidence for cholinergic modulation of excitatory neurotransmission. Proc Natl Acad Sci U S A 90:5194-5198. CrossRef Medline

Mrzljak L, Pappy M, Leranth C, Goldman-Rakic PS (1995) Cholinergic synaptic circuitry in the macaque prefrontal cortex. J Comp Neurol 357:603617. CrossRef Medline

Muller JF, Mascagni F, McDonald AJ (2011) Cholinergic innervation of pyramidal cells and parvalbumin-immunoreactive interneurons in the rat basolateral amygdala. J Comp Neurol 519:790-805. CrossRef Medline

Muller JF, Mascagni F, Zaric V, McDonald AJ (2013) Muscarinic cholinergic receptor M1 in the rat basolateral amygdala: ultrastructural localization and synaptic relationships to cholinergic axons. J Comp Neurol 521: 1743-1759. CrossRef Medline

Nitecka L, Frotscher M (1989) Organization and synaptic interconnections of GABAergic and cholinergic elements in the rat amygdaloid nuclei: single- and double-immunolabeling studies. J Comp Neurol 279:470488. CrossRef Medline

Pape HC, Driesang RB (1998) Ionic mechanisms of intrinsic oscillations in neurons of the basolateral amygdaloid complex. J Neurophysiol 79:217226. Medline

Power JM, Sah P (2008) Competition between calcium-activated K+ channels determines cholinergic action on firing properties of basolateral amygdala projection neurons. J Neurosci 28:3209-3220. CrossRef Medline

Rainnie DG, Mania I, Mascagni F, McDonald AJ (2006) Physiological and morphological characterization of parvalbumin-containing interneurons of the rat basolateral amygdala. J Comp Neurol 498:142-161. CrossRef Medline

Sah P, Faber ES, Lopez De Armentia M, Power J (2003) The amygdaloid complex: anatomy and physiology. Physiol Rev 83:803-834. Medline

Sarter M, Hasselmo ME, Bruno JP, Givens B (2005) Unraveling the attentional functions of cortical cholinergic inputs: interactions between signal-driven and cognitive modulation of signal detection. Brain Res Brain Res Rev 48:98-111. CrossRef Medline

Smith RS, Araneda RC (2010) Cholinergic modulation of neuronal excitability in the accessory olfactory bulb. J Neurophysiol 104:2963-2974. CrossRef Medline

Sosulina L, Graebenitz S, Pape HC (2010) GABAergic interneurons in the mouse lateral amygdala: a classification study. J Neurophysiol 104:617626. CrossRef Medline

Spampanato J, Polepalli J, Sah P (2011) Interneurons in the basolateral amygdala. Neuropharmacology 60:765-773. CrossRef Medline

Tinsley MR, Quinn JJ, Fanselow MS (2004) The role of muscarinic and nicotinic cholinergic neurotransmission in aversive conditioning: comparing pavlovian fear conditioning and inhibitory avoidance. Learn Mem 11:35-42. CrossRef Medline

Turrini P, Casu MA, Wong TP, De Koninck Y, Ribeiro-da-Silva A, Cuello AC (2001) Cholinergic nerve terminals establish classical synapses in the rat cerebral cortex: synaptic pattern and age-related atrophy. Neuroscience 105:277-285. CrossRef Medline

Umbriaco D, Watkins KC, Descarries L, Cozzari C, Hartman BK (1994) Ultrastructural and morphometric features of the acetylcholine innervations in adult rat parietal cortex: an electron microscopic study in serial sections. J Comp Neurol 348:351-373. CrossRef Medline

Washburn MS, Moises HC (1992) Muscarinic responses of rat basolateral amygdaloid neurons recorded in vitro. J Physiol 449:121-154. Medline

Womble MD, Moises HC (1992) Muscarinic inhibition of M-current and a potassium leak conductance in neurones of the rat basolateral amygdala. J Physiol 457:93-114. Medline

Womble MD, Moises HC (1993) Muscarinic modulation of conductances underlying the afterhyperpolarization in neurons of the rat basolateral amygdala. Brain Res 621:87-96. CrossRef Medline

Woodruff AR, Sah P (2007) Networks of parvalbumin-positive interneurons in the basolateral amygdala. J Neurosci 27:553-563. CrossRef Medline

Woolf NJ, Eckenstein F, Butcher LL (1983) Cholinergic projections from the basal forebrain to the frontal cortex: a combined fluorescent tracer and immunohistochemical analysis in the rat. Neurosci Lett 40:93-98. CrossRef Medline

Yajeya J, de la Fuente Juan A, Merchan MA, Riolobos AS, Heredia M, Criado JM (1997) Cholinergic responses of morphologically and electrophysiologically characterized neurons of the basolateral complex in rat amygdala slices. Neuroscience 78:731-743. CrossRef Medline

Yajeya J, de la Fuente Juan A, Bajo VM, Riolobos AS, Heredia M, Criado JM (1999) Muscarinic activation of a non-selective cationic conductance in pyramidal neurons in rat basolateral amygdala. Neuroscience 88:159167. CrossRef Medline

Yamasaki M, Matsui M, Watanabe M (2010) Preferential localization of muscarinic M1 receptor on dendritic shaft and spine of cortical pyramidal cells and its anatomical evidence for volume transmission. J Neurosci 30:4408-4418. CrossRef Medline

Zaborszky L, van den Pol A, Gyengesi E (2011) The basal forebrain cholinergic projection system in mice. In: The mouse nervous system (Watson C, Paxinos G, Puelles L, et al., eds), pp 684-718. London: Elsevier.

Zhang F, Aravanis AM, Adamantidis A, de Lecea L, Deisseroth K (2007) Circuit-breakers: optical techniques for probing neural signals and systems. Nat Rev Neurosci 8:577-581. CrossRef Medline 